\title{
Nickel-catalyzed carbocyanation of alkynes
}

$\operatorname{AUTHOR}(S)$ :

Nakao, Yoshiaki; Hiyama, Tamejiro

\section{CITATION:}

Nakao, Yoshiaki ... [et al]. Nickel-catalyzed carbocyanation of alkynes. Pure and Applied Chemistry 2008, 80(5): 1097-1107

\section{ISSUE DATE:}

2008-05

URL:

http://hdl.handle.net/2433/84649

\section{RIGHT:}

Copyright (c) 2008 International Union of Pure and Applied Chemistry 
Pure Appl. Chem., Vol. 80, No. 5, pp. 1097-1107, 2008.

doi:10.1351/pac200880051097

(c) 2008 IUPAC

\title{
Nickel-catalyzed carbocyanation of alkynes*
}

\author{
Yoshiaki Nakao ${ }^{\ddagger}$ and Tamejiro Hiyama \\ Department of Material Chemistry, Graduate School of Engineering, Kyoto \\ University, Kyoto 615-8510, Japan
}

\begin{abstract}
Nickel-catalyzed carbocyanation reaction of alkynes is described. Alkynes undergo aryl- and allylcyanation reaction in the presence of nickel-phosphine catalysts to give a wide range of substituted acrylonitriles in highly stereo-, regio-, and chemoselective manners. Lewis acid cocatalysts, such as $\mathrm{AlMe}_{3}, \mathrm{AlMe}_{2} \mathrm{Cl}$, and $\mathrm{BPh}_{3}$, are found to promote the arylcyanation significantly. The cooperative catalysis of nickel and Lewis acid also allows the carbocyanation reaction using alkenyl and alkyl cyanides.
\end{abstract}

Keywords: C-C bond activation; nickel; nitrile; addition reaction; homogeneous catalysis.

\section{INTRODUCTION}

Transition-metal-catalyzed cleavage of $\mathrm{C}-\mathrm{C}$ single bonds followed by addition of the resulting two organic groups across unsaturated $\mathrm{C}-\mathrm{C}$ bonds should be of great synthetic potential, because the transformation allows simultaneous formation of two $\mathrm{C}-\mathrm{C}$ bonds without forming by-products. The catalytic cycle of the transformation may involve oxidative addition of a $\mathrm{C}-\mathrm{C}$ bond followed by insertion of an unsaturated bond into the resulting $\mathrm{C}-\mathrm{M}$ bond and reductive elimination (Scheme 1). However, the oxidative addition of a $\mathrm{C}-\mathrm{C}$ bond to a metal is not feasible generally due to a directionally and sterically constrained $\mathrm{C}-\mathrm{C} \sigma$-bond having a high bond dissociation energy $(\sim 85 \mathrm{kcal} / \mathrm{mol})$ [1]. Accordingly, this catalytic transformation has been successful with strained C-C bonds of methylenecyclopropanes [2], cyclopropenones [3], cyclobutanes [4], cyclobutenones [5], and cyclobutanones [6]. On the other hand, $\mathrm{C}-\mathrm{CN}$ bonds in very common and ubiquitous nitriles are also cleavable upon treatment with certain transition-metal complexes, in spite of its higher bond dissociation energies ( $>100 \mathrm{kcal} / \mathrm{mol})$. The driving force of the elemental reaction would be attributable to high affinity to transition metals and electron-withdrawing nature of a cyano group as well as strong $\mathrm{M}-\mathrm{CN}$ bonds resulting from the activation of $\mathrm{C}-\mathrm{CN}$ bonds. Nitriles are known to coordinate to transition metals either in an $\eta^{1}$ - or $\eta^{2}$-fashion (Scheme 2) [7]. In particular, $\eta^{2}$-coordination further triggers the activation of a $\mathrm{C}-\mathrm{CN}$ bond via oxidative addition (path A) [8] or via formation of silylisonitrile complexes when a Lewis acidic silyl ligand is located on a metal (path B) [9]. A few seminal reports of catalytic reactions utilizing these elemental reactions including palladium-catalyzed insertion of unsaturated bonds into $\mathrm{C}(=\mathrm{O})-\mathrm{CN}$ bonds are available [ 10]. We envisioned that the oxidative addition of $\mathrm{C}-\mathrm{CN}$ bonds (path $\mathrm{A}$ in Scheme 2) would constitute an initiation step of the catalysis shown in Scheme 1 to achieve the addition reaction of nitriles across unsaturated bonds, namely, carbocyanation reaction. Especially, we focused our attention on the use of nickel as a catalyst, because the metal complexes have been demonstrated to be very reactive for the activation of $\mathrm{C}-\mathrm{CN}$ bonds. Herein, we briefly summarize our results of the carbocyanation reaction across alkynes [11].

\footnotetext{
*Paper based on a presentation at the $14^{\text {th }}$ International Symposium on Organometallic Chemistry Directed Towards Organic Synthesis (OMCOS-14), 2-6 August 2007, Nara, Japan. Other presentations are published in this issue, pp. 807-1194.

¥Corresponding author
} 


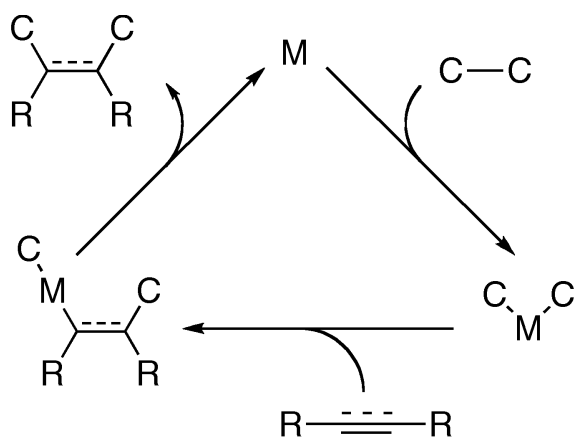

Scheme 1

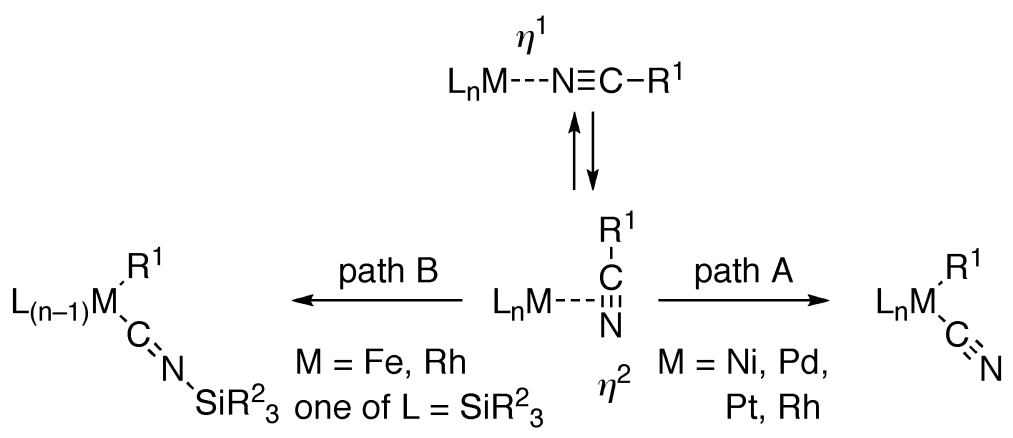

Scheme 2

\section{ARYLCYANATION}

We first investigated the arylcyanation reaction of alkynes. After screening catalysts and solvents effective for an equimolar reaction of 4-(trifluoromethyl)benzonitrile (1a) with 4-octyne (2a), we found that a combination of $\mathrm{Ni}(\mathrm{cod})_{2}$ and $\mathrm{PMe}_{3}$ was the optimum to give the corresponding cis-arylcyanation product in $80 \%$ yield after $24 \mathrm{~h}$ at $100{ }^{\circ} \mathrm{C}$ in toluene (entry 1 of Table 1). Benzonitriles having an electron-withdrawing substituent at the para-position reacted in good to excellent yields. A wide variety of functional groups including fluoro, keto, ester, and formyl were tolerated to give the corresponding arylcyanation products (entries 2-5). In particular, 1,4-dicyanobenzene (1f) reacted at one of the C-CN bonds exclusively with an equimolar amount of 4-octyne (2a) (entry 6), whereas double arylcyanation product 4 was obtained with two molar equivalents of $\mathbf{2 a}$ (eq. 1). The reaction rate and yield were inferior, with the substrates having an electron-neutral or -donating substituent at the para-position (entries 7-9). Meta- and ortho-substituents did not affect the reaction (entries 10-13). Heteroaryl cyanides also gave the corresponding adducts in modest to good yields (entries 14-19). 
Table 1 Arylcyanation of $\mathbf{2 a}$ with various aryl cyanides $\mathbf{1}$.

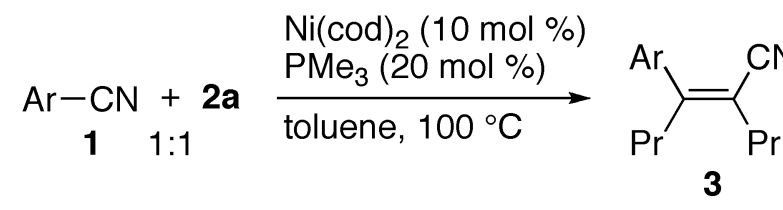

\begin{tabular}{|c|c|c|c|}
\hline entry & $\mathrm{Ar}$ & time $(h)$ & $\begin{array}{l}\text { yield of } \\
\mathbf{3}(\%)^{a)}\end{array}$ \\
\hline 1 & $4-\mathrm{F}_{3} \mathrm{C}-\mathrm{C}_{6} \mathrm{H}_{4}(\mathbf{1 a})$ & 24 & 80 (3aa) \\
\hline 2 & $4-\mathrm{F}-\mathrm{C}_{6} \mathrm{H}_{4}(\mathbf{1 b})$ & 30 & 81 (3ba) \\
\hline 3 & 4-Ac- $\mathrm{C}_{6} \mathrm{H}_{4}(1 \mathrm{c})$ & 30 & 73 (3ca) \\
\hline 4 & $4-\mathrm{MeO}_{2} \mathrm{C}-\mathrm{C}_{6} \mathrm{H}_{4}(\mathbf{1 d})$ & 24 & 96 (3da) \\
\hline 5 & $4-\mathrm{H}(\mathrm{O}) \mathrm{C}-\mathrm{C}_{6} \mathrm{H}_{4}(1 \mathrm{e})$ & 25 & 67 (3ea) \\
\hline 6 & $4-\mathrm{NC}-\mathrm{C}_{6} \mathrm{H}_{4}(\mathbf{1 f})$ & 19 & $67(3 \mathbf{f a})$ \\
\hline 7 & $\mathrm{Ph}(\mathbf{1 g})$ & 45 & 64 (3ga) \\
\hline 8 & $4-\mathrm{MeO}-\mathrm{C}_{6} \mathrm{H}_{4}(\mathbf{1 h})$ & 111 & 54 (3ha) \\
\hline 9 & 4-(pin) $\mathrm{B}-\mathrm{C}_{6} \mathrm{H}_{4}(1 \mathrm{i})$ & 30 & 61 (3ia) \\
\hline 10 & $3,5-(\mathrm{MeO})_{2}-\mathrm{C}_{6} \mathrm{H}_{3}(\mathbf{1} \mathbf{j})$ & 92 & 76 (3ja) \\
\hline 11 & $2-\mathrm{F}_{3} \mathrm{C}-\mathrm{C}_{6} \mathrm{H}_{4}(\mathbf{1 k})$ & 159 & 76 (3ka) \\
\hline 12 & $5-\mathrm{F}-2-\mathrm{Me}-\mathrm{C}_{6} \mathrm{H}_{3}(1 \mathrm{I})$ & 26 & 62 (3la) \\
\hline 13 & 2-naphthyl (1m) & 48 & 61 (3ma) \\
\hline $14^{\mathrm{b})}$ & 2 -furyl $(1 \mathrm{n})$ & 46 & 75 (3na) \\
\hline $15^{\mathrm{b})}$ & 2-thienyl (10) & 90 & 44 (3oa) \\
\hline 16 & 1-Boc-3-indolyl (1p) & 45 & 40 (3pa) \\
\hline 17 & 4-pyridyl (1q) & 24 & $85(3 q a)$ \\
\hline 18 & 3-pyridyl (1r) & 15 & 86 (3ra) \\
\hline $19^{b)}$ & 2-pyridyl (1s) & 44 & $\left.36(3 \mathbf{s a})^{c}\right)$ \\
\hline
\end{tabular}

a) Isolated yield. b) $\mathrm{PMe}_{2} \mathrm{Ph}$ as a ligand. ${ }^{\mathrm{c})} \mathrm{E} / Z=32: 68$.

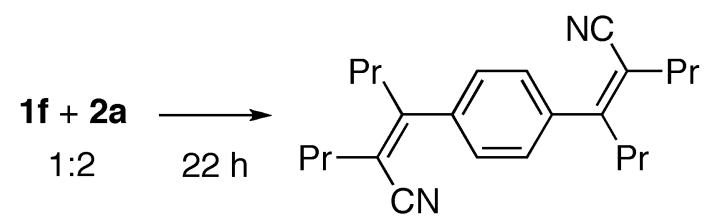

$4,80 \%$

The scope of alkynes with $\mathbf{1 d}$ as an aryl cyanide is shown in Table 2. Unsymmetrical alkynes gave a mixture of regioisomers, an isomer having a cyano group at the carbon bearing a larger substituent being favored (entries 2 and 3). Substitution of a heteroatom such as oxygen showed no significant influence on the regiochemistry (entry 4). Trimethyl(1-propynyl)silane (2f) also participated in the reaction with the same regiochemistry but gave a mixture of stereoisomers of $\mathbf{7 f}$ (entry 5). Predominant formation of cis-adduct $(E)-7 \mathbf{f}$ at the beginning of the reaction $(Z / E=15: 85$ at $1 \mathrm{~h})$ may suggest that the initial cis-adduct isomerizes under the reaction conditions. Terminal alkynes, such as 1-octyne and phenylacetylene, failed to participate in the reaction due presumably to rapid oligomerization and/or trimerization of alkynes. 
Table 2 Arylcyanation of alkynes using 1d.

\begin{tabular}{|c|c|c|c|c|c|c|}
\hline $\begin{array}{r}10 \\
+ \\
\mathrm{R}^{1}+\end{array}$ & $=-R^{2}$ & $2 \begin{array}{l}\mathrm{Ni}(\mathrm{cod} \\
\mathrm{PMe}_{3} \\
\text { toluene } \\
(\mathrm{Ar}=4\end{array}$ & $\begin{array}{r}\frac{2(10}{20 \mathrm{mc}} \\
, 100 \\
-\mathrm{MeO}\end{array}$ & $\begin{array}{l}\mathrm{mol} \%) \\
\text { ol \%) } \\
\stackrel{{ }^{\circ} \mathrm{C}}{\longrightarrow}\end{array}$ & 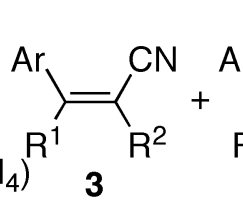 & ${ }_{\mathrm{R}^{2}}^{\mathrm{r}}=\mathrm{C}_{\mathbf{3}^{\prime}}^{\mathrm{C}}$ \\
\hline entry & $\mathrm{R}^{1}$ & $\mathrm{R}^{2}$ & & time (h) & yield $(\%)^{a)}$ & 3:3' \\
\hline 1 & $\mathrm{Me}$ & $\mathrm{Me}$ & $(2 b)$ & 20 & $70(\mathbf{3 d b})$ & - \\
\hline 2 & $\mathrm{Me}$ & $i-\operatorname{Pr}$ & $(2 c)$ & 26 & $84\left(3 \mathrm{dc}, 3^{\prime} \mathrm{dc}\right)$ & $62: 38$ \\
\hline 3 & $\mathrm{Me}$ & $t-\mathrm{Bu}$ & (2d) & 86 & 59 (3dd) & $>99: 1$ \\
\hline 4 & $\operatorname{Pr}$ & $\mathrm{CH}_{2} \mathrm{OMe}$ & $(2 e)$ & 67 & 59 (3de, 3'de) & $37: 63$ \\
\hline 5 & $\mathrm{Me}$ & $\mathrm{SiMe}_{3}$ & $(2 f)$ & 49 & $82\left(\mathbf{3 d f},{ }^{b)} \mathbf{3}^{\prime} \mathbf{d f}\right)$ & $85: 15$ \\
\hline
\end{tabular}

a) Isolated yield. ${ }^{\text {b) }} E / Z=41: 59$.

The catalysis is considered to be initiated by the oxidative addition of a $\mathrm{C}-\mathrm{CN}$ bond of an aryl cyanide to nickel(0) to give nickel(II) complex $\mathbf{D}$ through $\eta^{1}$ - and $\eta^{2}$-cyano-coordinating intermediates $\mathbf{A}$ and $\mathbf{B}$ followed by $\eta^{2}$-arene-coordinating intermediate $\mathbf{C}$ (Scheme 3) [12]. Then, an alkyne would coordinate to the nickel center to give pentacoordinate nickel species $\mathbf{E}$, which then would lose a phosphine ligand to give $\mathbf{F}$. The coordinating alkyne would be in the direction to avoid the steric repulsion between bulkier $\mathrm{R}^{2}$ and the aryl group on the nickel as depicted in $\mathbf{F}$. The aryl group would then migrate to the less hindered alkyne-carbon to give alkenylnickel $\mathbf{G}$ (arylnickelation), which upon recoordination of a phosphine ligand undergoes reductive elimination to afford $\mathbf{3}$ and regenerate the nickel $(0)$.

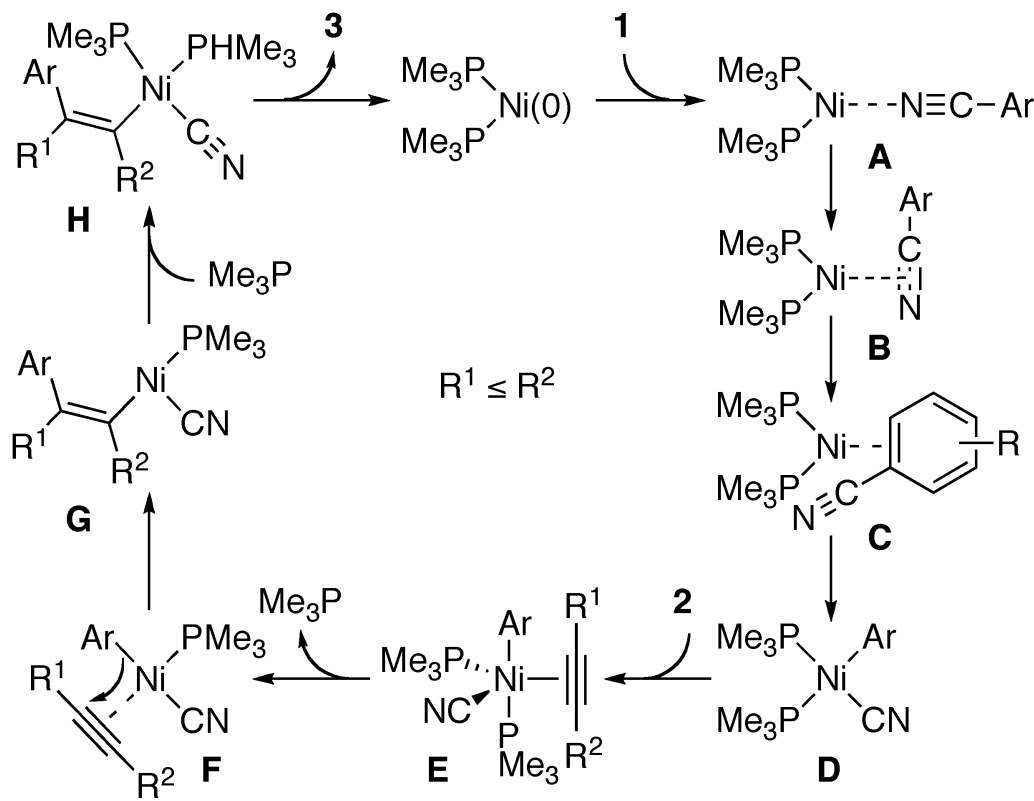

Scheme 3 
Based on the proposed catalytic cycle, we hypothesized that the arylcyanation reaction could be promoted by increasing the rate of the oxidative addition step because the observed order of reaction rate parallels qualitatively to that of the stoichiometric oxidative addition of $\mathrm{Ar}-\mathrm{CN}$ bonds to nickel( 0 ) with a positive $\rho$ value associated with a para-substituent of aryl cyanides as disclosed by Jones and coworkers [8j]. We envisioned that coordination of a cyano group to a Lewis acid (LA) [13] could make the cyano moiety a better "leaving group" and, thus, facilitate the oxidative addition. After a thorough survey of many combinations of $\mathrm{Ni}(\operatorname{cod})_{2}$, a ligand, and a catalytic amount of LA, we found that moderate $\mathrm{LAs}$ like $\mathrm{BPh}_{3}, \mathrm{AlMe}_{3}$, and $\mathrm{AlMe}_{2} \mathrm{Cl}$ in catalytic amount significantly promote the reaction to afford the arylcyanation product even with $1 \mathrm{~mol} \%$ of nickel catalyst at lower temperatures (entries 1 and 2 of Table 3 vs. entries 4 and 8 of Table 1). Under the newly developed binary catalysis, highly electron-rich 4-aminobenzonitriles, which were completely inert under the original conditions without LA, underwent the arylcyanation to give the corresponding adducts in good yields (entries 3 and 4). Highly remarkable is the selective activation of the $\mathrm{Ar}-\mathrm{CN}$ bonds over the Ar-halogen bonds in 4-chloro- (1v) and 4-bromobenzonitrile (1w) (entries 5 and 6). Even the sterically demanding $\mathrm{Ar}-\mathrm{CN}$ bond in 2,6-dimethylbenzonitrile (1x) underwent the reaction (entry 7). The selective activation of an Ar-CN bond over an Ar-H bond at C-2 in 1-methyl-3-cyanoindole (1y) demonstrates additional chemoselective feature of the present Ni-LA catalysis (entry 8), since the $\mathrm{Ar}-\mathrm{H}$ bond is activated exclusively in the absence of LA [14]. The observed dramatic effects of LA catalysis, we assume, is derived primarily from acceleration of the oxidative addition. However, such positive effects may also be operative in the reductive elimination of $\mathrm{C}-\mathrm{CN}$ bonds [15] and/or other elemental steps.

Table 3 Arylcyanation of $\mathbf{2 a}$ with aryl cyanides $\mathbf{1}$ catalyzed by nickel/Lewis acid.

\begin{tabular}{|c|c|c|c|c|c|c|}
\hline \multicolumn{2}{|c|}{$\begin{array}{c}\mathrm{Ar}-\mathrm{CN}+\mathbf{2 a} \\
\mathbf{1} 1: 1\end{array}$} & \multicolumn{2}{|c|}{$\begin{array}{l}\mathrm{Ni}(\mathrm{cod})_{2}(1 \mathrm{~mol} \%) \\
\text { ligand }(2 \mathrm{~mol} \%) \\
\text { Lewis acid }(4 \mathrm{~mol} \%)\end{array}$} & \multicolumn{2}{|c|}{$\left.{ }_{P r}^{A r}\right\rangle=<$} & SN \\
\hline entry & $\mathrm{Ar}$ & & cond. ${ }^{\text {a) }}$ & $\begin{array}{c}\text { temp } \\
\left({ }^{\circ} \mathrm{C}\right)\end{array}$ & $\begin{array}{c}\text { time } \\
\text { (h) }\end{array}$ & $\begin{array}{l}\text { yield of } \\
\mathbf{3}(\%)^{b)}\end{array}$ \\
\hline 1 & $4-\mathrm{MeO}_{2}$ & $\mathrm{C}_{6} \mathrm{H}_{4}(1 \mathrm{~d})$ & $A$ & 80 & 25 & 3da) \\
\hline 2 & 4-MeO- & ${ }_{6} \mathrm{H}_{4}(\mathbf{1 h})$ & A & 50 & 24 & 96 (3ha) \\
\hline 3 & $4-\mathrm{Me}_{2} \mathrm{~N}$ & $\mathrm{C}_{6} \mathrm{H}_{4}(\mathbf{t t})$ & $A$ & 80 & 21 & 87 (3ta) \\
\hline 4 & $4-\mathrm{Ph}_{2} \mathrm{~N}-$ & $\mathrm{C}_{6} \mathrm{H}_{4}(\mathbf{1 u})$ & B & 50 & 47 & 91 (3ua) \\
\hline 5 & $4-\mathrm{Cl}-\mathrm{C}_{6}$ & $f_{4}(1 v)$ & B & 50 & 18 & 94 (3va) \\
\hline $6^{c)}$ & $4-\mathrm{Br}-\mathrm{C}_{6}$ & $f_{4}(1 w)$ & $A$ & 50 & 27 & 72 (3wa) \\
\hline $7^{c)}$ & $2,6-\mathrm{Me}_{2}$ & ${ }_{6} \mathrm{H}_{3}(\mathbf{1 x})$ & A & 100 & 134 & $78(3 \times a)$ \\
\hline 8 & 1-Me-3- & idolyl (1y) & A & 50 & 116 & 58 (3ya) \\
\hline
\end{tabular}

a) A: $\mathrm{PMe}_{2} \mathrm{Ph}, \mathrm{AlMe}_{2} \mathrm{Cl} ; \mathrm{B}: \mathrm{PCyPh}_{2}, \mathrm{AlMe}_{3}{ }^{\text {b) }}$ Isolated yield.

c) $5 \mathrm{~mol} \%$ of the catalyst set was used.

\section{ALLYLCYANATION}

Oxidative addition of allyl cyanides is well known as an important elemental step in the nickel-catalyzed isomerization of 2-methyl-3-butenenitrile to 3- or 4-pentenenitrile through a $\pi$-allylnickel inter- 
mediate, the second step of DuPont's adiponitrile process [16]. We envisaged that a $\pi$-allylnickel intermediate could undergo allylnickelation across alkynes [17], and subsequent reductive elimination would complete a plausible catalytic cycle of allylcyanation reaction (Scheme 4). This was found to be the case. In the case of allylcyanation, $\mathrm{P}\left(4-\mathrm{CF}_{3}-\mathrm{C}_{6} \mathrm{H}_{4}\right)_{3}$ was found to be the ligand of choice. Variously substituted allyl cyanides underwent the addition reaction across $\mathbf{2 a}$ to give a range of $(Z)$ 2,5-hexadienenitriles (Table 4). Starting from 3-pentenenitrile (5b) and 2-methyl-3-butenenitrile (5c), the same crotylcyanation product $\mathbf{6 b a}$ was obtained as a mixture of stereoisomers (entries 2 and 3 ), suggesting a common $\pi$-allylnickel intermediate. No detectable amount of the adduct at the congested carbon was observed. The reactions of $(E)$-5,5-dimethyl-3-hexenenitrile (5d) and (E)-4-phenyl-3butenenitirile (5e) gave the corresponding linear adducts $\mathbf{6 d a}$ and $\mathbf{6 e a}$ as stereochemically pure forms (entries 4 and 5).

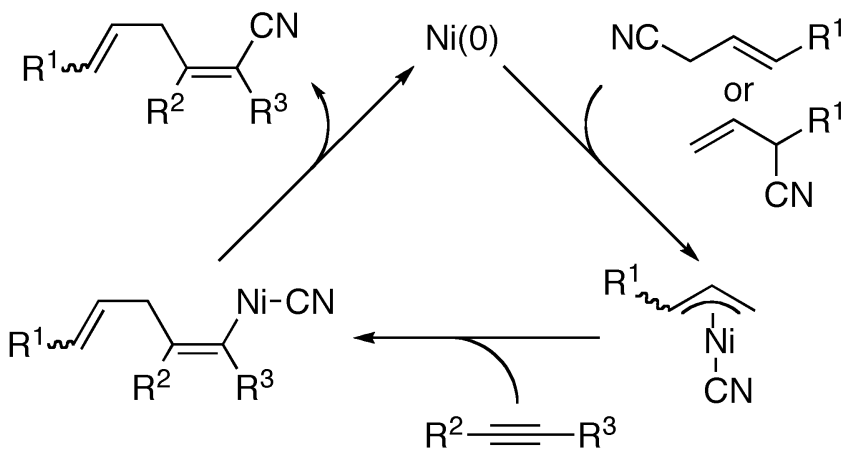

Scheme 4

Table 4 Allycyanation of 2a using substituted allyl cyanides.

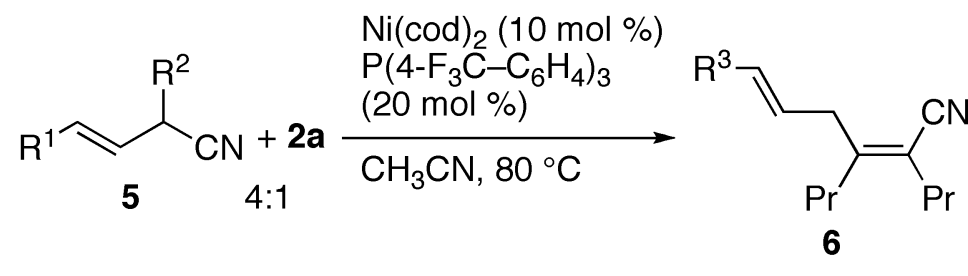

\begin{tabular}{clllccc}
\hline entry & $\mathrm{R}^{1}$ & $\mathrm{R}^{2}$ & $\mathrm{R}^{3}$ in $\mathbf{6}$ & time $(\mathrm{h})$ & $\begin{array}{l}\text { yield of } \\
\mathbf{6}(\%)^{\mathrm{a})}\end{array}$ & $5 E / 5 Z$ \\
\hline 1 & $\mathrm{H}$ & $\mathrm{H}(\mathbf{5 a})$ & $\mathrm{H}$ & 8 & $78(\mathbf{6 a a})$ & - \\
2 & $\mathrm{Me}$ & $\mathrm{H}(\mathbf{5 b})$ & $\mathrm{Me}$ & 17 & $55(\mathbf{6 b a})$ & $83: 17$ \\
3 & $\mathrm{H}$ & $\mathrm{Me}(\mathbf{5 c})$ & $\mathrm{Me}$ & 17 & $69(\mathbf{6 b a})$ & $85: 15$ \\
4 & $t-\mathrm{Bu}$ & $\mathrm{H}(\mathbf{5 d})$ & $t-\mathrm{Bu}$ & 18 & $49(\mathbf{6 d a})$ & $>99: 1$ \\
5 & $\mathrm{Ph}$ & $\mathrm{H}(\mathbf{5 e})$ & $\mathrm{Ph}$ & 18 & $86(\mathbf{6 e a})$ & $>99: 1$ \\
\hline
\end{tabular}

a) Isolated yield.

The addition of $\alpha$-siloxyallyl cyanide $\mathbf{5 f}$ proceeded at the $\gamma$-carbon exclusively to give aldehyde 6fa after acidic hydrolysis (Scheme 5). Formation of a silyl enol ether as an initial product of the present catalytic reaction was proved by using tert-butyldimethylsilyloxyallyl cyanide (5g), affording the corresponding silyl enol ether $\mathbf{6 g a}$ in $87 \%$ yield as a mixture of stereoisomers. 


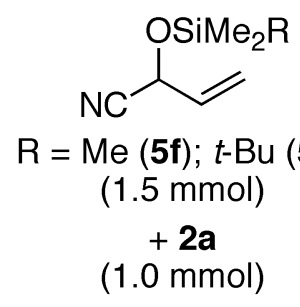

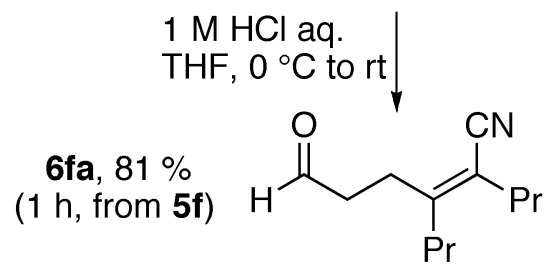

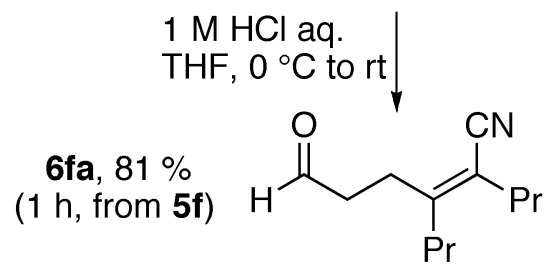

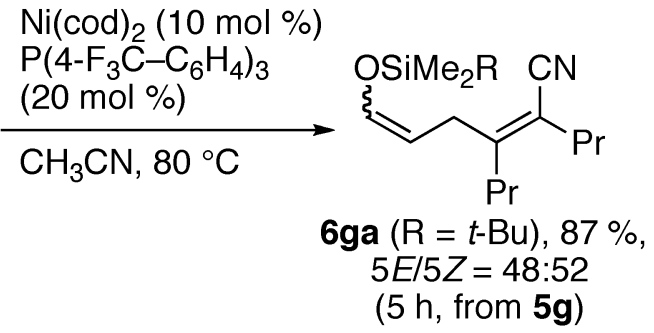

\section{Scheme 5}

Other $\alpha$-siloxyallyl cyanides having a substituent at the $\alpha$ - or $\beta$-position underwent the addition reaction successfully (entries 1-4 of Table 5), whereas the reaction of $\gamma$-substituted one $\mathbf{5 l}$ did not give any adduct due presumably to steric repulsion (entry 5). A variety of alkynes including terminal ones participated in the addition reaction to give a mixture of regioisomers. Isomers having a larger substituent at a cyano-substituted carbon were obtained preferentially (entries 7-14). Functional groups such as chloro, ester, and phthalimide were tolerated (entries 11-13).

Table 5 Allycyanation of alkynes using $\alpha$-siloxyallyl cyanides.
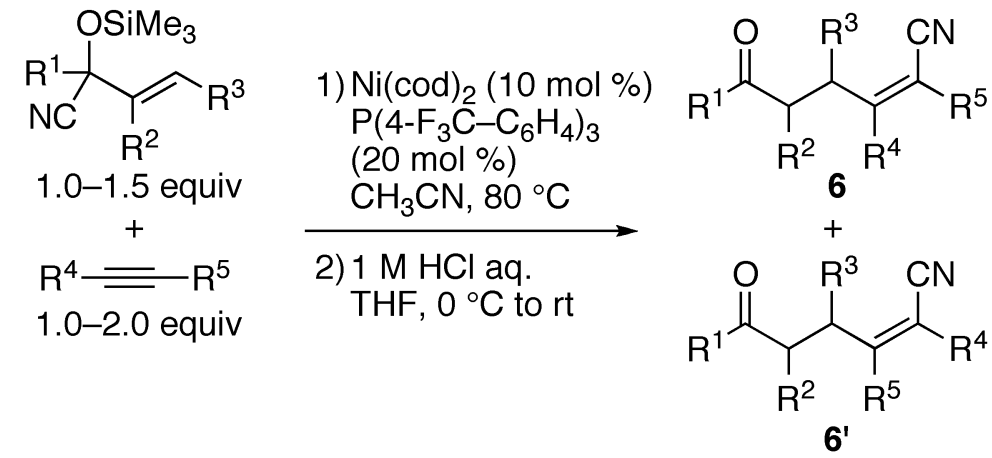

\begin{tabular}{|c|c|c|c|c|c|c|}
\hline entry & $R^{1} R^{2}$ & $\mathrm{R}^{3}$ & $R^{4} R^{5}$ & $\begin{array}{c}\text { time } \\
\text { (h) }\end{array}$ & $\begin{array}{l}\text { yield } \\
(\%)^{a)}\end{array}$ & $6: 6^{\prime}$ \\
\hline $1^{b)}$ & $\mathrm{Me} \mathrm{H}$ & $H(5 h)$ & $\operatorname{Pr} \operatorname{Pr}(\mathbf{2 a})$ & 2 & 71 (6ha) & - \\
\hline $2^{b)}$ & Et $\mathrm{H}$ & $H(5 \mathbf{i})$ & $\operatorname{Pr} \operatorname{Pr}(\mathbf{2 a})$ & 3 & 81 (6ia) & - \\
\hline $3^{b)}$ & $\mathrm{Ph} \mathrm{H}$ & $H(5 \mathbf{j})$ & $\operatorname{Pr} \operatorname{Pr}(\mathbf{2 a})$ & 2 & 54 (6ja) & - \\
\hline 4 & $\mathrm{H} \quad \mathrm{Me}$ & $H(5 k)$ & $\operatorname{Pr} \operatorname{Pr}(\mathbf{2 a})$ & 12 & 69 (6ka) & - \\
\hline $5^{c)}$ & $\mathrm{H} \mathrm{H}$ & $\mathrm{Ph}(5 \mathrm{I})$ & $\operatorname{Pr} \operatorname{Pr}(\mathbf{2 a})$ & 1 & $<5$ (6la) & - \\
\hline 6 & $\mathrm{H} \mathrm{H}$ & $H(\mathbf{5 f})$ & $\mathrm{Me} \mathrm{Me}(\mathbf{2 b})$ & 1 & 58 (6fb) & - \\
\hline 7 & $\mathrm{H} \mathrm{H}$ & $H(\mathbf{5 f})$ & Me Et $(\mathbf{2 g})$ & 1 & $58\left(\mathbf{6} \mathbf{f g}, \mathbf{6}^{\prime} \mathbf{f g}\right)$ & $61: 39$ \\
\hline
\end{tabular}

(continues on next page) 
Table 5 (Continued).

\begin{tabular}{|c|c|c|c|c|c|c|c|c|}
\hline entry & & $R^{2}$ & $R^{3}$ & $\mathrm{R}^{4}$ & $\mathrm{R}^{5}$ & $\begin{array}{c}\text { time } \\
\text { (h) }\end{array}$ & $\begin{array}{c}\text { yield } \\
(\%)^{a)}\end{array}$ & $6: 6^{\prime}$ \\
\hline 8 & $\mathrm{H}$ & $\mathrm{H}$ & $H(\mathbf{5 f})$ & $\mathrm{Me}$ & $\mathrm{Ph}(2 \mathrm{~h})$ & 1 & 70 (6fh) & $93: 7$ \\
\hline 9 & $\mathrm{H}$ & $\mathrm{H}$ & $H(\mathbf{5 f})$ & $\mathrm{H}$ & $\operatorname{Hex}(\mathbf{2} \mathbf{i})$ & 1 & 74 (6fi, 6'fi) & $92: 8$ \\
\hline 10 & $\mathrm{H}$ & $\mathrm{H}$ & $H(\mathbf{5 f})$ & $\mathrm{H}$ & $t$-Bu (2j) & 1 & $61(6 \mathrm{fj})$ & $>99: 1$ \\
\hline 11 & $\mathrm{H}$ & $\mathrm{H}$ & $H(\mathbf{5 f})$ & $\mathrm{H}$ & $\left(\mathrm{CH}_{2}\right)_{3} \mathrm{Cl}(\mathbf{2 k})$ & 1 & 78 (6fk) & $95: 5$ \\
\hline 12 & $\mathrm{H}$ & $\mathrm{H}$ & $H(\mathbf{5 f})$ & $\mathrm{H}$ & $\left(\mathrm{CH}_{2}\right)_{3} \mathrm{CO}_{2} \mathrm{Me}(2$ & 2I)1 & $62(6 \mathrm{fl})$ & $95: 5$ \\
\hline 13 & $\mathrm{H}$ & $\mathrm{H}$ & $H(\mathbf{5 f})$ & $\mathrm{H}$ & $\left(\mathrm{CH}_{2}\right)_{4} \mathrm{NPhth}(2 \mathrm{~m}$ & m)1 & $60\left(\mathbf{6 f m}, \mathbf{6}^{\mathbf{f m}}\right.$ & n) $90: 10$ \\
\hline 14 & $\mathrm{H}$ & $\mathrm{H}$ & $H(\mathbf{5 f})$ & $\mathrm{H}$ & $\mathrm{SiMe}_{3}(\mathbf{2 n})$ & 1 & 36 (6fn) & $>99: 1$ \\
\hline
\end{tabular}

a) Isolated yield. b) The reaction was carried out in toluene at $120^{\circ} \mathrm{C}$.

c) The reaction was carried out at $100{ }^{\circ} \mathrm{C}$.

\section{ALKENYLCYANATION}

The carbocyanation reaction using alkenyl cyanides has also been achieved by the aid of Ni-LA dual catalysis (Table 6). $\mathrm{BPh}_{3}$ was found to be the optimum LA catalyst for the alkenylcyanation, because stronger LAs, such as $\mathrm{AlMe}_{3}$ and $\mathrm{AlMe}$ Cl, caused isomerization of the initial cis-adduct to give a mixture of stereoisomers. In this particular carbocyanation process, it is worth noting that the catalyst differentiates precisely the alkenyl-CN bonds of starting alkenyl cyanides from those of products possibly by steric and/or electronic factors. Starting with variously substituted alkenyl cyanides, a range of 2,4-pentadienenitriles were obtained in good yields. Selective activation of the cyano group trans to the phenyl group of benzylidenemalononitrile (7e) to give dicyano-substituted 1,3-diene (8ea) has also been achieved (entry 5).

Table 6 Alkenylcyanation of 2a catalyzed by nickel/ $\mathrm{BPh}_{3}$.

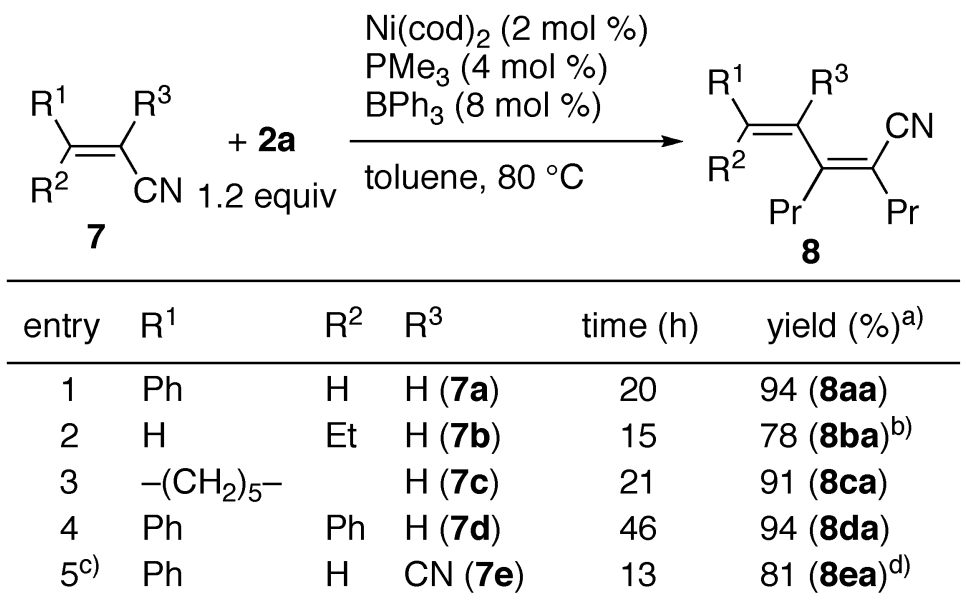

a) Isolated yield. b) $4 E / 4 Z=16: 84{ }^{\text {c) }} \mathrm{Ni}(\mathrm{cod})_{2}(4 \mathrm{~mol} \%)$, dppb (4 mol \%), and $\mathrm{BPh}_{3}\left(16 \mathrm{~mol} \%\right.$ ) were used. ${ }^{\mathrm{d})} \sim 2 \%$ of an isomer was also obtained. 


\section{ALKYLCYANATION}

Even alkyl cyanides are activated and undergo the carbocyanation reaction by Ni-LA catalysis. For example, acetonitrile (9a) added across 4-octyne (2a) in the presence of a $\mathrm{Ni}-\mathrm{AlMe}_{3}$ catalyst to give methylcyanation product 10aa in $71 \%$ yield with a $10 \mathrm{mmol}$ scale (eq. 2). The addition of $\mathrm{CH}_{3} \mathrm{CN}-d_{3}$ gave the corresponding 10aa- $d_{3}$ of $99 \%$ deuteriation, demonstrating that the methyl group in 10aa is fully derived from acetonitrile and definitely not from $\mathrm{AlMe}_{3}$. On the other hand, propionitrile (9b) gave ethylcyanation product (10ba) in a low yield together with $(E)$-2-propyl-2-hexenenitrile (11), which should be derived from oxidative addition of $\mathrm{Et}-\mathrm{CN}$ bond to $\mathrm{Ni}(0)$ followed by $\beta$-hydride elimination and hydrocyanation of $\mathbf{2 a}$ (Scheme 6).
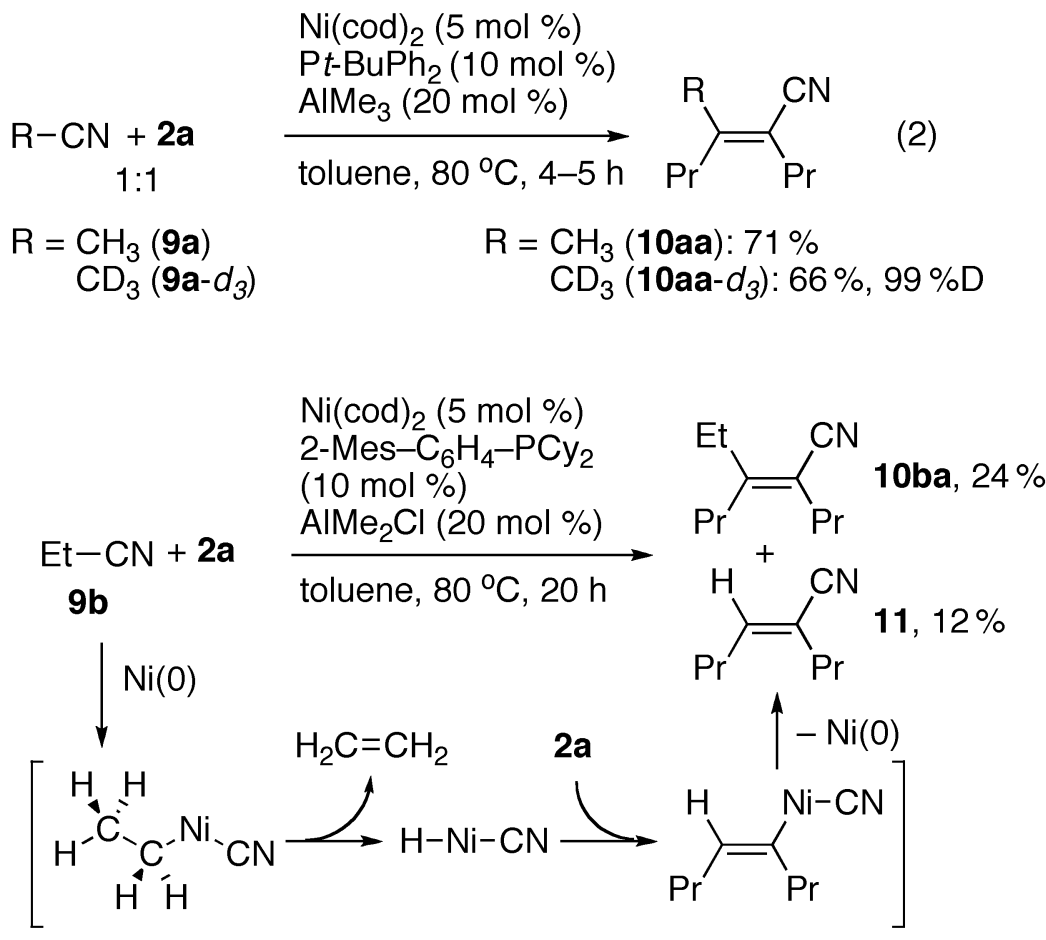

Scheme 6

The nickel-catalyzed carbocyanation reaction across alkynes has been demonstrated. By the assist of LA catalysts, a wide variety of nitriles including aryl, allyl, alkenyl, and alkyl cyanides now participate in the reaction. The addition reaction takes place in general with high stereo- and regioselectivities, providing a rapid and atom-economical access to variously substituted acrylonitriles. Future efforts in this field will be directed to further optimization of the Ni-LA dual catalysis for the broadened scope of alkyl cyanides as well as other unsaturated compounds, especially simple alkenes. 


\section{REFERENCES}

1. (a) D. Milstein, B. Rybtchinski. Angew. Chem., Int. Ed. 38, 871 (1999); (b) M. Murakami, Y. Ito. Top. Organomet. Chem. 3, 97 (1999); (c) C.-H. Jun. Chem. Soc. Rev. 33, 610 (2004).

2. (a) R. Noyori, T. Odagi, H. Takaya. J. Am. Chem. Soc. 92, 5780 (1970); (b) A. Baba, Y. Ohshiro, T. Agawa. J. Organomet. Chem. 110, 121 (1976); (c) P. Binger, B. Schäfer. Tetrahedron Lett. 29, 4539 (1988); (d) S. Saito, M. Masuda, S. Komagawa. J. Am. Chem. Soc. 126, 10540 (2004); (e) S. Komagawa, S. Saito. Angew. Chem., Int. Ed. 45, 2446 (2006); (f) S. Saito, K. Takeuchi. Tetrahedron Lett. 48, 595 (2007); (g) K. Maeda, S. Saito. Tetrahedron Lett. 48, 3173 (2007).

3. T. Kondo, Y. Kaneko, Y. Taguchi, A. Nakamura, T. Okada, M. Shiotsuki, Y. Ura, K. Wada, T. Mitsudo. J. Am. Chem. Soc. 124, 6824 (2002).

4. (a) R. Noyori, T. Suzuki, H. Takaya. J. Am. Chem. Soc. 93, 5896 (1971); (b) B. L. Edelbach, R. J. Lachicotte, W. D. Jones. Organometallics 18, 4040 (1999); (c) C. N. Iverson, W. D. Jones. Organometallics 20, 5745 (2001); (d) C. Müller, R. J. Lachicotte, W. D. Jones. Organometallics 21, 1975 (2002); (e) T. Schaub, M. Backes, U. Radius. Organometallics 25, 4196 (2006).

5. (a) M. A. Huffman, L. S. Liebeskind. J. Am. Chem. Soc. 113, 2771 (1991); (b) T. Kondo, Y. Taguchi, Y. Kaneko, M. Niimi, T. Mitsudo. Angew. Chem., Int. Ed. 43, 5369 (2004).

6. (a) M. Murakami, T. Itahashi, Y. Ito. J. Am. Chem. Soc. 124, 13976 (2002); (b) T. Matsuda, A. Fujimoto, M. Ishibashi, M. Murakami. Chem. Lett. 33, 876 (2004); (c) M. Murakami, S. Ashida, T. Matsuda. J. Am. Chem. Soc. 127, 6932 (2005); (d) M. Murakami, S. Ashida, T. Matsuda. J. Am. Chem. Soc. 128, 2166 (2006); (e) M. Murakami, S. Ashida. Chem. Commun. 4599 (2006).

7. B. N. Storhoff, H. C. Lewis Jr. Coord. Chem. Rev. 23, 1 (1977).

8. (a) J. L. Burmeister, L. M. Edwards. J. Chem. Soc. A 1663 (1971); (b) D. H. Gerlach, A. R. Kane, G. W. Parshall, J. P. Jesson, E. L. Muetterties. J. Am. Chem. Soc. 93, 3543 (1971); (c) G. W. Parshall. J. Am. Chem. Soc. 96, 2360 (1974); (d) D. A. Clarke, M. M. Hunt, D. W. Kemmitt. J. Organomet. Chem. 175, 303 (1979); (e) A. Morvillo, A. Turco. J. Organomet. Chem. 208, 103 (1981); (f) G. Favero, A. Morvillo, A. Turco. J. Organomet. Chem. 241, 251 (1983); (g) C. Bianchini, D. Masi, A. Meli, M. Sabat. Organometallics 5, 1670 (1986); (h) M. Abla, T. Yamamoto. J. Organomet. Chem. 532, 267 (1997); (i) D. Churchill, J. H. Shin, T. Hascall, J. M. Hahn, B. M. Bridgewater, G. Parkin. Organometallics 18, 2403 (1999); (j) J. J. García, N. M. Brunkan, W. D. Jones. J. Am. Chem. Soc. 124, 9547 (2002); (k) Q.-X. Liu, F.-B. Xu, Q.-S. Li, H.-B. Song, Z.-Z. Zhang. Organometallics 23, 610 (2004); (1) N. M. Brunkan, D. M. Brestensky, W. D. Jones. J. Am. Chem. Soc. 126, 3627 (2004); (m) J. J. García, A. Arévalo, N. M. Brunkan, W. D. Jones. Organometallics 23, 3997 (2004); (n) T. A. Atesin, T. Li, S. Lachaize, W. W. Brennessel, J. J. García, W. D. Jones. J. Am. Chem. Soc. 129, 7562 (2007).

9. (a) F. L. Taw, P. S. White, R. G. Bergman, M. Brookhart. J. Am. Chem. Soc. 124, 4192 (2002); (b) F. L. Taw, A. H. Mueller, R. G. Bergman, M. Brookhart. J. Am. Chem. Soc. 125, 9808 (2003); (c) H. Nakazawa, T. Kawasaki, K. Miyoshi, C. H. Suresh, N. Koga. Organometallics 23, 117 (2004); (d) H. Hashimoto, A. Matsuda, H. Tobita. Organometallics 25, 472 (2006).

10. Catalytic reactions via path A: (a) J. Blum, E. Oppenheimer, E. D. Bergmann. J. Am. Chem. Soc. 89, 2338 (1967); (b) S. Murahashi, T. Naota, N. Nakajima. J. Org. Chem. 51, 898 (1986); (c) K. Nozaki, N. Sato, H. Takaya. J. Org. Chem. 59, 2679 (1994); (d) K. Nozaki, N. Sato, H. Takaya. Bull. Chem. Soc. Jpn. 69, 1629 (1996); (e) J. A. Miller. Tetrahedron Lett. 42, 6991 (2001); (f) J. A. Miller, J. W. Dankwardt. Tetrahedron Lett. 44, 1907 (2003); (g) J. A. Miller, J. W. Dankwardt, J. M. Penney. Synthesis 1643 (2003); (h) J. M. Penney, J. A. Miller. Tetrahedron Lett. 45, 4989 (2004); (i) Y. Nishihara, Y. Inoue, M Itazaki, K. Takagi. Org. Lett. 7, 2639 (2005); (j) Y. Nishihara, Y. Inoue, S. Izawa, M. Miyasaka, K. Tanemura, K. Nakajima, K. Takagi. Tetrahedron 62, 9872 (2006); (k) Y. Kobayashi, H. Kamisaki, R. Yanada, Y. Takemoto. Org. Lett. 8, 2711 (2006); (1) Y. Kobayashi, H. Kamisaki, H. Takeda, Y. Yasui, R. Yanada, Y. Takemoto. 
Tetrahedron 63, 2978 (2007); catalytic reactions via path B: (m) H. Nakazawa, K. Kamata, M. Itazaki. Chem. Commun. 4004 (2005); (n) M. Tobisu, Y. Kita, N. Chatani. J. Am. Chem. Soc. 128, 8152 (2006); (o) H. Nakazawa, M. Itazaki, K. Kamata, K. Ueda. Chem. Asian J. 2, 882 (2007).

11. (a) Y. Nakao, S. Oda, T. Hiyama. J. Am. Chem. Soc. 126, 13904 (2004); (b) Y. Nakao, S. Oda, A. Yada, T. Hiyama. Tetrahedron 62, 7567 (2006); (c) Y. Nakao, T. Yukawa, Y. Hirata, S. Oda, J. Satoh, T. Hiyama. J. Am. Chem. Soc. 128, 7116 (2006); (d) Y. Nakao, A. Yada, S. Ebata, T. Hiyama. J. Am. Chem. Soc. 129, 2428 (2007).

12. Theoretical calculations have suggested that the oxidative addition of aryl halides to $\operatorname{Pd}(0)$ also proceeds via an arene-coordinative species, see: (a) H. M. Senn, T. Ziegler. Organometallics 23, 2980 (2004); (b) L. J. Gooßen, D. Koley, H. L. Hermann, W. Thiel. Organometallics 24, 2398 (2005).

13. K. Starowieyski, S. Pasynkiewicz, M. Boleslawski. J. Organomet. Chem. 10, 393 (1967).

14. (a) Y. Nakao, K. S. Kanyiva, S. Oda, T. Hiyama. J. Am. Chem. Soc. 128, 8146 (2006); (b) K. S. Kanyiva, Y. Nakao, T. Hiyama. Heterocycles 72, 677 (2007).

15. J. Huang, C. M. Haar, S. P. Nolan, J. E. Marcone, K. G. Moloy. Organometallics 18, 297 (1999).

16. (a) R. J. McKinney. In Homogeneous Catalysis, G. W. Parshall (Ed.), p. 42, John Wiley, New York (1992); (b) J. I. van der Vlugt, A. C. Hewat, S. Neto, R. Sablong, A. M. Mills, M. Lutz, A. L. Spek, C. Müller, D. Vogt. Adv. Synth. Catal. 346, 993 (2004); (c) A. Chaumonnot, F. Lamy, S. Sabo-Etienne, B. Donnadieu, B. Chaudret, J.-C. Barthelat, J.-C. Galland. Organometallics 23, 3363 (2004); (d) J. Wilting, C. Müller, A. C. Hewat, D. D. Ellis, D. M. Tooke, A. L. Spek, D. Vogt. Organometallics 24, 13 (2005); (e) A. Acosta-Ramirez, A. Flores-Gasper, M. MunozHernandez, A. Arevalo, W. D. Jones, J. J. García. Organometallics 26, 1712 (2007).

17. (a) F. Guerrieri, G. P. Chiusoli. J. Organomet. Chem. 15, 209 (1968); (b) S. Ikeda, Y. Sato. J. Am. Chem. Soc. 116, 5975 (1994); (c) S. Ikeda, D.-M. Cui, Y. Sato. J. Org. Chem. 59, 6877 (1994); (d) M. Kimura, A. Ezoe, M. Mori, Y. Tamaru. J. Am. Chem. Soc. 127, 201 (2005); (e) M. L. Nadal, J. Bosch, J. M. Vila, G. Klein, S. Ricart, J. M. Moretó. J. Am. Chem. Soc. 127, 10476 (2005). 